\title{
BACE1 Gene
}

National Cancer Institute

\section{Source}

National Cancer Institute. BACE1 Gene. NCI Thesaurus. Code C112893.

This gene plays a role in protein cleavage. 